\title{
Internal Controls For Hospitality Revenue In The Gaming Industry
}

Tim Kizirian, California State University, Chico, USA

Tim Heinze, California State University, Chico, USA

John (Skip) Lees, California State University, Chico, USA

\begin{abstract}
In today's difficult economic climate, business managers must carefully consider all aspects of business operations to minimize waste and increase efficiency. The revenue cycle continues to be the primary area of fraud and abuse requiring strong, comprehensive internal controls (AICPA 2002). Internal controls in the revenue arena are now more important than ever. The current paper provides a control review checklist for hospitality revenue in the gaming industry. Extant studies have often focused on internal controls for the gambling operations of the gaming industry to the neglect of the hospitality portion of the industry. For many firms in the industry, the hospitality revenue can account for half of total firm revenue. The checklist we provide can be used as a general benchmark to perform preliminary evaluations of a company's internal control system in the hospitality arena. Auditors can compare their client's control objectives with the objectives that are presented. During preliminary investigations of the company's internal control system, auditors should review whether important control objectives have been omitted and whether the omission incurs or heightens risk. The control review checklist can also be used by CFOs or controllers in the gaming industry in reviewing whether their company's internal control systems are adequate. The checklist provides CFOs or controllers internal controls that external, independent auditors consider to be important.
\end{abstract}

Keywords: internal control; control objectives; hospitality

\section{INTRODUCTION}

\section{History And Trends In The Gaming Industry}

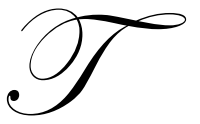

oday some people believe that the term "gaming industry" was invented to give the world of gambling a more respectable image. However, the American Gaming Association indicates that the term "gaming", the action or habit of playing at games of chance for stakes, has been around since

1510, preceding the word "gambling" by 265 years (American Gaming Association, 2009).

The gaming (or gambling) industry consists of companies that provide, own, operate, or engage in lawful gaming activities and facilities related to gaming and leisure. Casinos, state lotteries, pari-mutuel wagering, charitable gambling, and firms that manufacture gaming machines are all important components of the industry (Hoovers, 2009).

Two factors that have contributed to the rapid growth of the gaming industry in recent years are that society now considers gambling to be socially acceptable and a form of entertainment and that many state governments are using it to generate a major source of revenue (Hoovers, 2009).

The majority of gaming industry revenue comes from casinos based in commercial hotels and Indian reservations. Ironically though, over time gambling revenue has become less important to the profitability of these companies, while non-gaming operations, including restaurants, lodging, retail outlets, and entertainment attractions, contribute a large percentage (more than half in some cases) of the casino's overall sales (Hoovers, 2009). 
With a decrease in tourist visits hotel casinos are now courting small and mid-size company business meetings. The result is increased revenue from the lodging, restaurant, entertainment, and gambling activities. To encourage the traditional tourist visits some casinos are even offering child-care facilities to free up the parents to spend more time gambling (Hoovers, 2009).

In 2007 the US gaming industry generated over $\$ 92$ billion in gross revenue. The $\$ 92$ billion came from 3 main sources. Large commercial casino operations, such as MGM Mirage and Harrah's Entertainment, were responsible for about $\$ 34$ billion. Indian casinos generated \$26 billion, state lotteries accounted for almost \$25 billion, and the remaining $\$ 7$ billion came from pari-mutuel wagering, charitable games and bingo, card rooms, and legal bookmaking (American Gaming Association, 2009). The gaming industry is rather top heavy with the largest 20 companies garnering more than $60 \%$ market share (Hoovers, 2009).

In the early days of the gaming industry the internal audit function was merely designed to protect the daily casino gambling receipts. As the industry has grown the need for much stronger security and internal controls, and expansion of those controls to the hospitality feature of the industry has increased dramatically. The audit profession has become an extremely important part of daily casino management.

According to an article published by the Institute of Internal Auditors (IIA), some of the main factors that motivate the audit function in the gaming industry are "the U.S. Sarbanes-Oxley Act of 2002, the widespread use of technology in gaming, increased reliance on our computer systems to operate and manage the casino floor, and continued pressure by management to conduct more efficient audits" (Institute of Internal Auditors, 2005).

\section{The Revenue Cycle Review Checklist}

Tables 1 and 2 present a checklist of control objectives and activities that should be referenced when conducting a preliminary audit of hospitality revenue in the gaming industry. Table 1 lists significant revenue cycle control objectives. The objectives are followed by alpha numeric characters that reference the control activities listed in Table 2. The numeric portion of the reference explicitly refers to the control activities (listed numerically in Table 2), and the alpha portion ("F" or "P") indicates whether or not the referenced activity "fully" or "partially" meets the given objective's requirements.

Table 1: Control Objectives And Suggested Control Activities

\begin{tabular}{|l|l|}
\hline Control Objectives & Control Activities \\
\hline Services are not provided if customer's credit worthiness does not meet established standards. & $16 \mathrm{~F}, 32 \mathrm{P}$ \\
\hline Room rates, food and beverage prices, and banquet contracts are approved by management. & $17 \mathrm{~F}, 21 \mathrm{P}$ \\
\hline Rates, terms and customer information is input accurately. & $18 \mathrm{~F}, 20 \mathrm{P}, 31 \mathrm{P}$ \\
\hline $\begin{array}{l}\text { Sales are transferred completely and accurately to the system which generates room, food and } \\
\text { beverage, and banquet revenues. }\end{array}$ & $19 \mathrm{~F}, 20 \mathrm{P}, 30 \mathrm{P}, 31 \mathrm{P}, 33 \mathrm{P}, 34 \mathrm{P}$ \\
\hline Invoices are generated using authorized terms and rates. & $17 \mathrm{~F}, 18 \mathrm{~F}$ \\
\hline Invoices are accurately calculated and recorded. & $4 \mathrm{P}, 29 \mathrm{~F}$ \\
\hline Adjustments to accounts receivable are accurately calculated and recorded. & $4 \mathrm{P}, 6 \mathrm{P}, 8 \mathrm{P}, 34 \mathrm{P}$ \\
\hline All customers are invoiced. & $20 \mathrm{P}, 22 \mathrm{~F}, 33 \mathrm{P}$ \\
\hline Invoices relate to valid sales. & $13 \mathrm{P}, 22 \mathrm{~F}, 31 \mathrm{P}$ \\
\hline All invoices issued are recorded. & $3 \mathrm{P}, 19 \mathrm{~F}, 20 \mathrm{P}, 34 \mathrm{P}$ \\
\hline Invoices are recorded in the appropriate period. & $3 \mathrm{P}, 19 \mathrm{~F}, 33 \mathrm{P}$ \\
\hline $\begin{array}{l}\text { Accounts Receivable reflect the existing business circumstances and economic conditions in } \\
\text { accordance with the accounting policies being used. }\end{array}$ & $7 \mathrm{~F}$ \\
\hline Cash receipts are recorded in the period in which they are received. & $9 \mathrm{~F}, 23 \mathrm{~F}, 24 \mathrm{~F}, 28 \mathrm{P}$ \\
\hline Cash receipts data is entered for processing accurately. & $13 \mathrm{P}, 23 \mathrm{~F}, 24 \mathrm{P}, 25 \mathrm{P}, 26 \mathrm{P}, 27 \mathrm{P}, 28 \mathrm{P}$ \\
\hline All cash receipts data is entered for processing. & $13 \mathrm{P}, 23 \mathrm{~F}, 24 \mathrm{P}, 26 \mathrm{P}, 27 \mathrm{~F}, 28 \mathrm{P}$ \\
\hline Cash receipts data is valid and is entered for processing only once. & $23 \mathrm{~F}, 24 \mathrm{P}, 27 \mathrm{P}, 28 \mathrm{P}$ \\
\hline Timely collection of accounts receivable is monitored. & $1 \mathrm{P}, 2 \mathrm{P}$ \\
\hline Only valid changes are made to the customer master file. & $5 \mathrm{P}, 10 \mathrm{~F}, 14 \mathrm{P}, 30 \mathrm{P}$ \\
\hline All valid changes to the customer master file are input and processed. & $11 \mathrm{~F}, 14 \mathrm{P}, 15 \mathrm{P}, 31 \mathrm{P}$ \\
\hline Changes to the customer master file are accurate. & $10 \mathrm{~F}, 12 \mathrm{P}, 14 \mathrm{P}, 31 \mathrm{P}, 30 \mathrm{P}$ \\
\hline Changes to the customer master file are processed timely. & $11 \mathrm{~F}, 14 \mathrm{P}, 15 \mathrm{P}, 31 \mathrm{P}$ \\
\hline Customer master files data remain pertinent. & $14 \mathrm{P}, 30-34 \mathrm{P}$ \\
\hline
\end{tabular}


Table 2: Suggested Control Activities

\begin{tabular}{|c|c|}
\hline 1 & Accounts receivable aging reports are prepared regularly and analyzed. \\
\hline 2 & Collection procedures established by management for overdue accounts are performed as intended. \\
\hline 3 & $\begin{array}{l}\text { Room, food and beverage, banquet and other miscellaneous revenues are compared to budget regularly; management } \\
\text { reviews and approves significant variances. }\end{array}$ \\
\hline 4 & Invoices are edited and validated; identified errors are corrected promptly. \\
\hline 5 & Significant changes to customer master files are approved by management. \\
\hline 6 & Management approves customer charge-backs, bad-debt write-offs and other adjustments to accounts receivable. \\
\hline 7 & Management reviews and approves the allowance for doubtful debts. \\
\hline 8 & $\begin{array}{l}\text { Management monitors the nature, volume, and amounts of customer charge-backs, write-offs and other adjustments to } \\
\text { accounts receivable. }\end{array}$ \\
\hline 9 & $\begin{array}{l}\text { Cash receipts at, before, or after the end of an accounting period are scrutinized and/or reconciled to ensure complete and } \\
\text { consistent recording in the appropriate accounting period. }\end{array}$ \\
\hline 10 & $\begin{array}{l}\text { Recorded changes to customer master file data are compared to authorized source documents or confirmed with customers } \\
\text { to ensure that data was input accurately. }\end{array}$ \\
\hline 11 & $\begin{array}{l}\text { Requests to change customer master file data are logged; the log is reviewed to ensure that all requested changes are } \\
\text { processed timely. }\end{array}$ \\
\hline 12 & Customer master file input data is edited and validated; identified errors are corrected promptly. \\
\hline 13 & Accounts receivable statements are mailed periodically to direct bill customers. \\
\hline 14 & Customer master file data is periodically reviewed by management for accuracy and ongoing pertinence. \\
\hline 15 & $\begin{array}{l}\text { Requests to change customer master file data are submitted on pre-numbered forms; the numerical sequence of such forms } \\
\text { is accounted for. }\end{array}$ \\
\hline 16 & $\begin{array}{l}\text { Rooms are not sold and banquets are not reserved without receipt of valid credit card, advance payment or other } \\
\text { arrangement specifically approved by management. For direct bill customers management approval for charges should be } \\
\text { obtained. }\end{array}$ \\
\hline 17 & $\begin{array}{l}\text { Sales terms and prices are based on approved price list. Exceptions to standard pricing and discounts require specific } \\
\text { management approval. Overrides of standard pricing and terms are reported and investigated by management. }\end{array}$ \\
\hline 18 & $\begin{array}{l}\text { Room rates and terms are compared to signed registration card. Food, beverage and other charges are compared to } \\
\text { approved pricing lists (for charges such as parking) or independent source documents (such as food and beverage checks } \\
\text { and banquet contracts). }\end{array}$ \\
\hline 19 & $\begin{array}{l}\text { Daily room, food and beverage, banquet and other miscellaneous revenues per invoices are reconciled to the general ledger } \\
\text { on a daily basis; identified errors are corrected promptly. }\end{array}$ \\
\hline 20 & $\begin{array}{l}\text { Invoices, food and beverage checks, and banquet contracts are sequentially pre-numbered. The sequence of invoices, food } \\
\text { and beverage checks, and banquet contracts processed is accounted for. }\end{array}$ \\
\hline 21 & Significant or unusual sales are specifically approved by management as to rates and terms. \\
\hline 22 & $\begin{array}{l}\text { Management compares daily guest ledger to daily housekeeping records and reconciles occupied rooms to recorded sales } \\
\text { on a daily basis. }\end{array}$ \\
\hline 23 & $\begin{array}{l}\text { Cash sales are recorded using a cash register. Customers are provided with a copy of the register receipt and total daily } \\
\text { receipts per the register are balanced to cash deposited to the bank. }\end{array}$ \\
\hline 24 & Bank statements are reconciled to the general ledger regularly. \\
\hline 25 & Cash receipts input data is edited and validated; identified errors are corrected promptly. \\
\hline 26 & Cash receipts transactions are batched and batch input data is balanced; out-of-balance batches are corrected promptly. \\
\hline 27 & $\begin{array}{l}\text { Customers are provided with a form acknowledging receipt of any cash payments (i.e., a cash receipt form) and cash } \\
\text { receipts forms are balanced to cash deposited to the bank. Cash receipt forms are sequentially pre-numbered and the } \\
\text { sequence of such forms is accounted for. }\end{array}$ \\
\hline 28 & $\begin{array}{l}\text { General ledger balances are reconciled to the accounts receivable subsidiary ledger and differences are resolved in a timely } \\
\text { manner. }\end{array}$ \\
\hline 29 & Invoices are independently recalculated. \\
\hline 30 & $\begin{array}{l}\text { The information system restricts to authorized personnel the ability to create, change, or delete sales orders, contracts, and } \\
\text { delivery schedules. }\end{array}$ \\
\hline 31 & The information system edits and validates order entry transactions on-line. \\
\hline 32 & The information system does not allow processing of sales orders that exceed customer credit limits. \\
\hline 33 & The information system reports of gaps in document numbering are reviewed regularly. \\
\hline 34 & $\begin{array}{l}\text { General ledger balances are reconciled to the accounts receivable subsidiary ledger and differences are resolved in a timely } \\
\text { manner. }\end{array}$ \\
\hline
\end{tabular}




\section{SUMMARY AND CONCLUSION}

The current paper provides an internal control checklist for hospitality revenue that, when used as a benchmark for comparative purposes, will aid managers and independent auditors in the gaming industry. The checklist will be useful in preliminarily assessing the design of internal controls in the area of hospitality revenue. In light of today's difficult economic environment, and the increasing importance of hospitality revenue to the gaming industry, the checklist is both important and timely.

\section{ACKNOWLEDGEMENT}

The authors wish to thank the management of a large anonymous CPA firm for allowing access to documents which were useful in the preparation of this paper.

\section{AUTHOR BIOGRAPHIES}

Tim Kizirian, Ph.D., CPA, is a Professor at California State University, Chico. He received his MBA from Cal Poly, San Luis Obispo and his M.A. and Ph.D. from the University of Arizona, and has worked for a Big Four CPA firm. He can be reached at (530) 898-6389 or at tkizirian@ csuchico.edu.

Tim Heinze, Ph.D., is a Marketing Lecturer at California State University, Chico. He received his MS from Texas A\&M University and his Ph.D. from Capella University. He has worked for a Detroit Three automotive firm. He can be reached at (530)898-6090 or at tcheinze@ csuchico.edu.

John (Skip) Lees, Ph.D., is an Associate Professor at California State University, Chico. He received his Ph.D. from the University of Florida. He has co-authored a textbook on database management systems. He can be reached at (530) 898-4821 or at slees@ csuchico.edu.

\section{REFERENCES}

1. American Gaming Association. (2009). Industry Information : Facts Sheets. Retrieved November 9, 2009 from http://www.americangaming.org/Industry/factsheets/index.cfm

2. Gambling Industry Overview by Hoovers. (2009). Industry Description, Trends, and Financial Summary. Retrieved November 9, 2009 from http://industries.hoovers.com/leisure/gambling

3. Gaming Auditorium - The Institute of Internal Auditors. (2005). Auditing the Casino Floor - An Update. An Interview with Craig Robinson by Jody Whitley, Editor. Vol. 8, No. 1 - First Quarter, 2005. Retrieved November 9, 2009 from http://www.theiia.org/Gaming/index.cfm?iid=366

4. Gaming Informatics LLC. (2009). Software for the Highly Regulated Industry of Gaming. Retrieved November 9, 2009 from http://www.gaminginformatics.com/about/who-we-are 